\title{
Multi-Criteria Decision Making and Dempster-Shafer Model Based Delineation of Groundwater Prospect Zones From A Semi-Arid Environment
}

\section{Hemant Kumar Pandey}

Motilal Nehru National Institute of Technology

Vishal Kumar Singh ( $\nabla$ spaceimage@outlook.com )

MNNIT: Motilal Nehru National Institute of Technology https://orcid.org/0000-0003-2892-7505

\section{Sudhir Kumar Singh}

University of Allahabad Faculty of Science

\section{Research Article}

Keywords: Multi-criteria decision making (MCDM), Analytical hierarchy process (AHP), Groundwater potential, Bundelkhand Hydrological evaluations.

Posted Date: November 17th, 2021

DOl: https://doi.org/10.21203/rs.3.rs-947367/v1

License: (c) (i) This work is licensed under a Creative Commons Attribution 4.0 International License. Read Full License

Version of Record: A version of this preprint was published at Environmental Science and Pollution Research on February 19th, 2022. See the published version at https://doi.org/10.1007/s11356-02219211-0. 


\title{
1 Multi-Criteria Decision Making and Dempster-Shafer Model Based Delineation of Groundwater Prospect Zones From A Semi-Arid Environment
}

${ }^{1}$ Associate Professor, Department of Civil Engineering, Motilal Nehru National Institute of Technology Allahabad, Prayagraj-211004, Uttar Pradesh, India hkp@mnnit.ac.in

\author{
${ }^{2}$ Research Scholar, Department of Civil Engineering, Motilal Nehru National Institute of \\ Technology Allahabad, Prayagraj-211004, Uttar Pradesh, India \\ spaceimage@ outlook.com
}
${ }^{3}$ Assistant Professor (Stage-III), K. Banerjee Centre of Atmospheric \& Ocean Studies, IIDS, Nehru Science Centre, University of Allahabad, Prayagraj-211002, Uttar Pradesh, India sudhirinjnu@gmail.com

\section{Acknowledgment:}

Authors are thankful to the NRDMS, DST, Govt. of India for providing the financial support in the mode of R\&D project. Thanks are also due to the Director, MNNIT Allahabad, Prayagraj, India for his administrative support. We are thankful to Dr. P. K Mehta, Head of the department, Civil Engineering, MNNIT Allahabad, Prayagraj for his continuous support and encouragement during the research work.

Interest Statement

The present research work doesn't have any conflict of interest with the researchers who have done the work in this area. The findings of the present research work will provide a road map for making the plan for water management. 
Abstract

The present study illustrates the delineation of the groundwater potential zones in one of the most critical and

\section{Introduction}

Rainwater is the only source of freshwater and the occurrence of rainfall is seasonal in nature, resulting into mild to severe droughts (Adimalla et al. 2018). Groundwater has key impacts on human life such as agriculture, industries and ecological diversity. With the increment in the demand for adequate and better quality water to meet the growing needs, a proper planning of groundwater management is essential (Agrawal 2013). As per the assessment by Central Ground Water Board India (CGWB 2017), total annual groundwater recharge is 432 billion cubic meters (BCM), and the annual exploitable groundwater resources is $393 \mathrm{BCM}$. The annual groundwater withdrawal for all uses is 249 BCM out of which $221 \mathrm{BCM}(89 \%)$ is used for irrigation and $25 \mathrm{BCM}(10 \%)$ is used for domestic purposes. According to a World Bank (2016) report, India will become a water-stress country by 2025 and a water-scarce country by 2050 , if not enough measures are taken. Due to rapid urbanization and population growth, excessive and unjustified use of groundwater has caused depletion of groundwater tables which reiterate the need for better understanding of groundwater potential zones (Islam et al. 2021).

In the recent past, many methods have been used by several researchers to delineate the groundwater potential zone. Weights-of-Evidence (WOE) technique was used as an effective method for delineation of groundwater potential zones by Ozdemir, (2011); Pourtaghi and Pourghasemi, (2014). Some researchers like Oh et al. (2011); Moghaddam et al. (2015) have also used the Frequency Ratio (FR) technique for identifying groundwater potential zones. The Analytical Hierarchy Process (AHP) analysis by GIS technique was used by Pande et al. (2019); Singh et al. (2010); Shekhar and Pandey (2014); Rahmati et al. (2014); Murmu et al. (2019) and Adiat et al. (2012) to delineate the groundwater potential zone. 
GIS and analytical hierarchy process (AHP) is the most useful technique for decision making and geospatial data management. This is applicable in various fields of hydrological, geological and environmental science (Gnanachandrasamy 2018). AHP technique is proven to be a very practical, rapid and cost effective technique to map the groundwater potential zones and in producing accurate results while traditionally groundwater exploration was costly and time consuming. Because it needed ground survey using geophysical, geological and hydrological tools (Arulbalaji 2019). Nowadays, remotely sensed data is being widely used to provide baseline information such as digital elevation model (DEM), digital terrain model (DTM), land use/land cover etc., which are further used for preparation of several geospatial thematic maps required for the delineation of groundwater potential zones. Suja and Krishnan (2009), Nag and Ghosh (2012), Suganthi (2013), and Etishree (2013) Weightages based on Saaty's (1980) scale for distinct thematic maps utilized to identify groundwater potential zones. According to Doke et al. (2018), Das (2019), Adimalla (2020), and Arjun et al. (2021) geological and geomorphological setup are the most influencing factors for groundwater occurrence. As per Debasis et al. (2020) shallow unconfined aquifers, deeper fractures and joints under semi-confined conditions are the important indicators of groundwater potential in hard rock terrains. Many researchers Adimalla et al. (2018); Arulbalaji (2019); Gangadharan et al. (2016) have used various thematic layers like drainage density, geology, lineament density, slope, soil and lithology for the identification of groundwater potential zones.

Another approach to delineate the groundwater potential map is the Dempster-Shafer ( $D S$ ) model, which has been predominantly used by many researchers (Mogaji et al. 2018; Ali et al. 2017; Nithya et al. 2018; Sahereh et al. 2021) around the world. The main reason to use the DS model is that it provides a set of probabilistic degrees such as Belief, Disbelief, Plausibility and Uncertainty. The link between obtained thematic layers of probabilistic degree illustrates groundwater potential zones, which is further classified into five categories; Very High, High, Medium, Low and Very Low.

As the groundwater is an extractable asset with this intervention most groundwater management authorities ignore support services and other in situ groundwater functions, the authorities need to adopt an integrated approach to control excessive extraction of groundwater considering environmental management (Gun 2021). The AHP and DS model for the accurate mapping of groundwater potential have been used in the present study.

\section{Study Area}

The district Mahoba is located in Uttar Pradesh state of India, lies between $25^{\circ} 01^{\prime} 30^{\prime \prime}$ and $25^{\circ} 39^{\prime} 40^{\prime \prime}$ north latitude and $79^{\circ} 15^{\prime} 00^{\prime \prime}$ and $80^{\circ} 10^{\prime} 30^{\prime \prime}$ east longitude (Fig. 1). The total geographical area of the district is $2,884 \mathrm{~km}^{2}$. It has four administrative blocks and five towns. According to the Census of India (2011) the total population of the district is 875958 . The district experiences a typical subtropical climate punctuated by long and intense summers. Mild winter and moderately heavy rainfall during the rainy season. The maximum mean monthly atmospheric temperature has been recorded $47.5^{\circ} \mathrm{C}$ during the month of May and minimum $8.3^{\circ} \mathrm{C}$ in January. Temperature generally starts rising from March and reaches highest in May. June onward temperature starts decreasing and almost establishes around $36^{\circ}$ $\mathrm{C}$ during August and September. During the monsoon period (July to September) the relative humidity attains at its highest level which varies between 80 to $85 \%$ while it is lowest at $30 \%$ during peak summer months of April and May. Major soil type is sandy deep loamy while average rainfall for the last 10 years is estimated to be $770 \mathrm{~mm}$. There is no meteorological observatory located in Mahoba district, however five rain gauge stations have been established by the UP irrigation department (Pandey 2002).

The rock formations of the Bundelkhand massif is characterised by compact and partially granite which do not allow rain to percolate and store under subsurface. Secondary porosity in the form of joints and cracks, allows some water to pass through weather zones into phreatic aquifers(Pant 2011). The hilly and hard rock terrain cause heavy overland flow and water during the rainy season. As a result, base flow occurs in the river as a part of groundwater. 


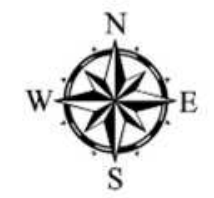

Agriculture being the main source of livelihood for the people of Mahoba district requires excessive extraction of groundwater, both groundwater and surface water are used for irrigation purposes. Most of the agricultural land depends upon precipitation. Swami Brahmanand Dam with storage capacity of 89.8 Billion liters and Arjun Sagar Reservoir with storage capacity of 16.6 Billion liters are the two major basins which collect most of the rainwater through run-off. Total length of the irrigation canals is approximately $455 \mathrm{~km}$. Dhasan, Urmil, Birna and Arjun rivers follow through the district, these rivers and streams form the natural drainage lines of the district and separate many administrative boundaries.

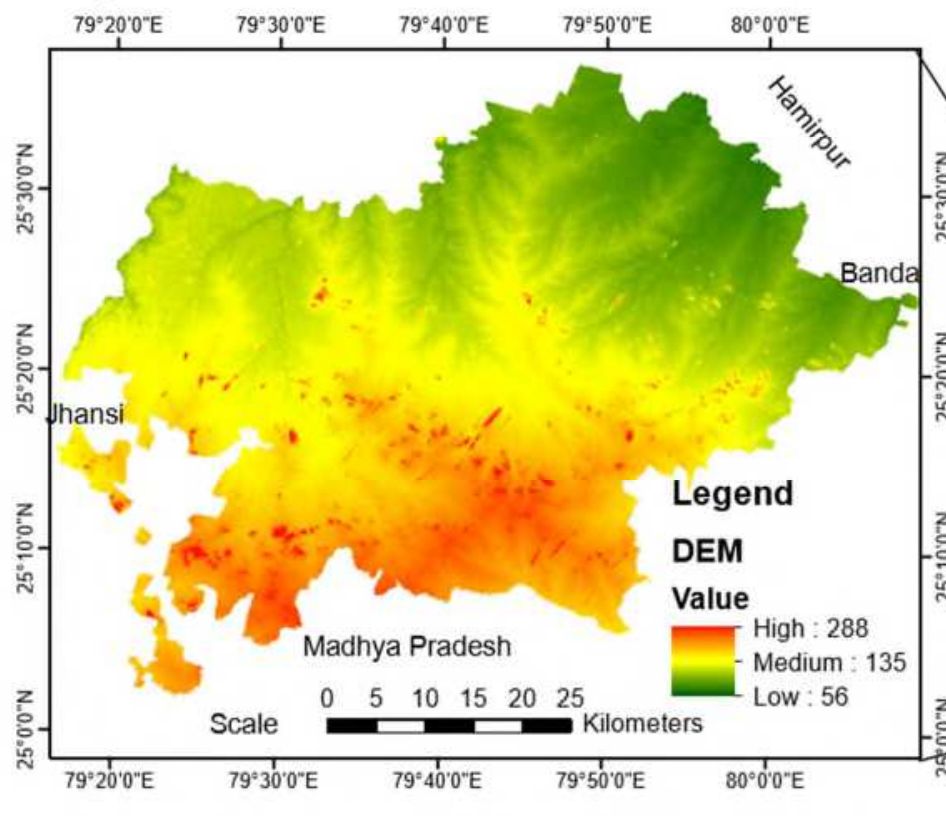

Fig. 1 Location map of the study area 


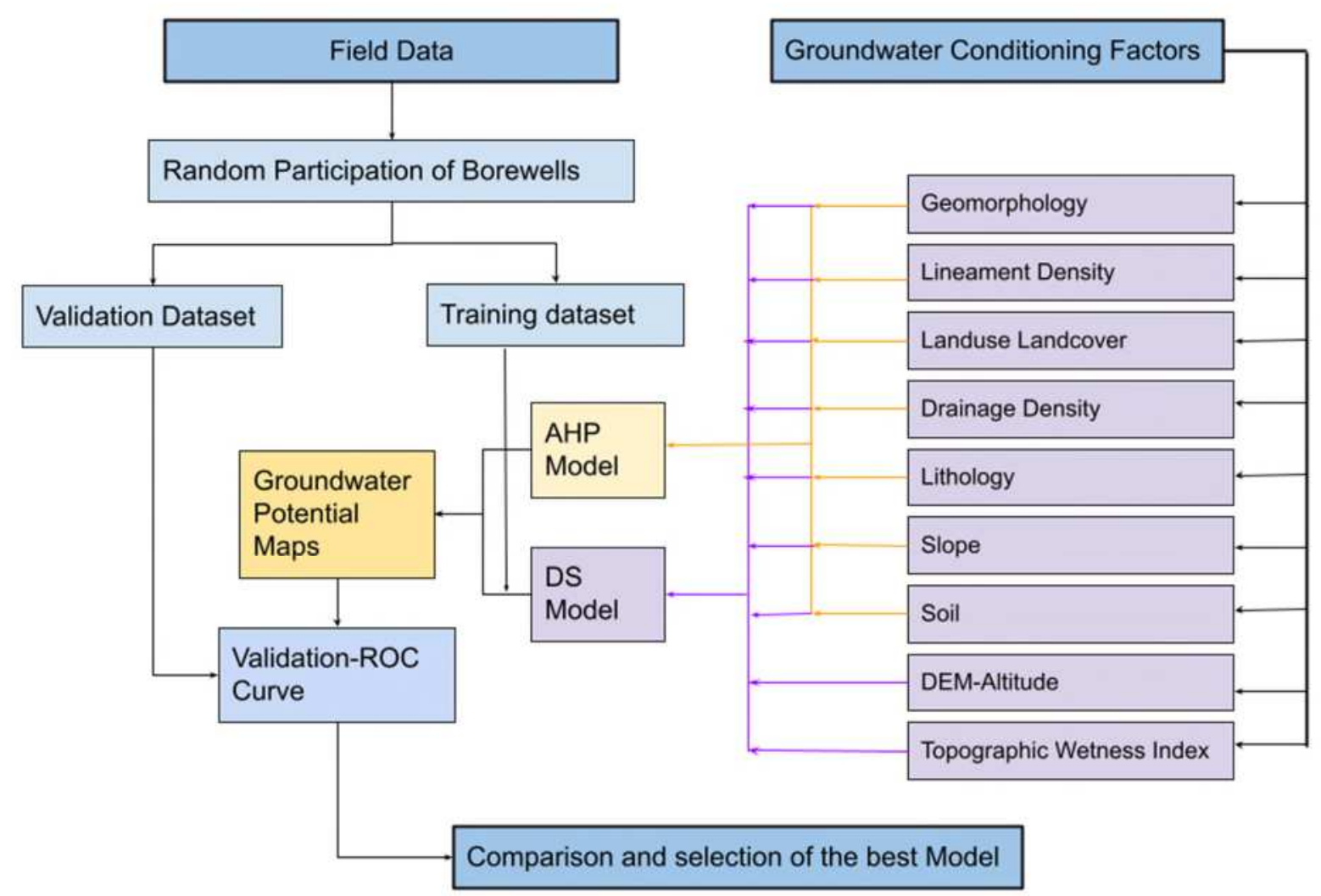

Fig. 2 Flow chart of methodology adopted for the delineation of groundwater potential maps

Pre-processing of remotely sensed data i.e. Sentinel 2 was done using ArcGIS software, which is used for preparing thematic layer of land use/land cover, the data have a spatial resolution of $10 \mathrm{~m}$ for blue, green, red and infrared bands which gives more accurate details about features of the earth surface (Cavur 2019). Analysis of thematic layers such as geomorphology, lithology, soil, land use/land cover, slope, drainage density, lineament density, altitude and topographic wetness index (TWI) were considered. The data pertaining to the study area were downloaded from the European Space Agency website (https://scihub.copernicus.eu/). CartoDEM data were used for generating Digital Elevation Model (DEM), altitude, lineament density, and topographic wetness index, which have 30m of resolution and downloaded from National Remote Sensing Center's website called Bhuvan (https://bhuvanapp3.nrsc.gov.in/data/download/). It is processed in ArcMap platform to generate flow accumulation with direction. Flow direction of streams represent the drainage network of the study area, and resulted into a thematic layer of drainage density. The DEM data is also used for the preparation of slope which is an important factor for delineation of groundwater potential zone. It mainly represents movement of water on the surface which is known as surface runoff. The steps involved to delineate the groundwater potential zone have been depicted in Fig. 2.

Ancillary data pertaining to thematic layers as geomorphology (scale 1:250K) and lithology (scale 1:50K) were collected from Bhukosh portal (https://bhukosh.gsi.gov.in/Bhukosh/Public) of Geological Survey of India, Whereas; soil map was downloaded http://www.nicraicar.in/nicrarevised/images/statewiseplans/Uttar\%20Pradesh/UP50-Mahoba-26.07.14.pdf) National Bureau of Soil 
soil type for the selected region of Mahoba district is deep loamy soil with very low slope $(<3 \%-5 \%)$. Selected thematic layers were further processed using multi-criteria decision making (MCDM) technique of AHP and DS model. Finally weighted overlay analysis has been carried out to calculate overall weightages for each thematic layer. The maps were further classified into five categories under groundwater potential zones. Borewells data have been used for the validation of the groundwater potential zones. The receiver operating characteristics $(R O C)$ curve method was also employed to compare the groundwater potential zones maps obtained from both the models.

\section{Analytical Hierarchical Process (AHP)}

Analytical Hierarchical Process (AHP) is a practical and most common method based on GIS to delineate the groundwater potential zones. This method is useful to integrate several hydrological thematic layers (Arulbalaji 2019). Out of nine thematic layers only seven were selected to delineate the potential zones in the study area. The weightage for the selected thematic layers was computed using Saaty's scale (1980). According to Gangadharan et al. (2016) Weight assignment, pairwise comparison matrix, weight normalisation, and consistency assessment are all part of the AHP model. This strategy is capable of decreasing the problem complexity and assisting in the adoption of simplified decisions based on comparisons (Kannan 2010; Celik 2019).

All the thematic layers were given importance which were used for weightage calculation (Table-1). The proposed ranking of the thematic features defines weightages values. Further, to compare all of the factors, a pair-wise comparison matrix $(W)$ was created (Eq. 1). Using the eigen-vector technique described by Saaty, the process of normalizing weights (Wij) is derived (Eq. 2) from the matrix table (Table 2). (Neissi et al. 2020; Nithya et al. 2019). The geometric mean of the $i^{\text {th }}$ factor is $m$.

Table 1: Importance of Thematic layers for weightage calculation

\begin{tabular}{|c|c|c|c|c|c|c|}
\hline \multicolumn{7}{|c|}{ Thematic layers } \\
\hline Lineament density & Geomorphology & Slope & Lithology & Soil & $\begin{array}{l}\text { Drainage } \\
\text { Density }\end{array}$ & LULC \\
\hline 6 & 4 & 4 & 3 & 3 & 3 & 2 \\
\hline
\end{tabular}

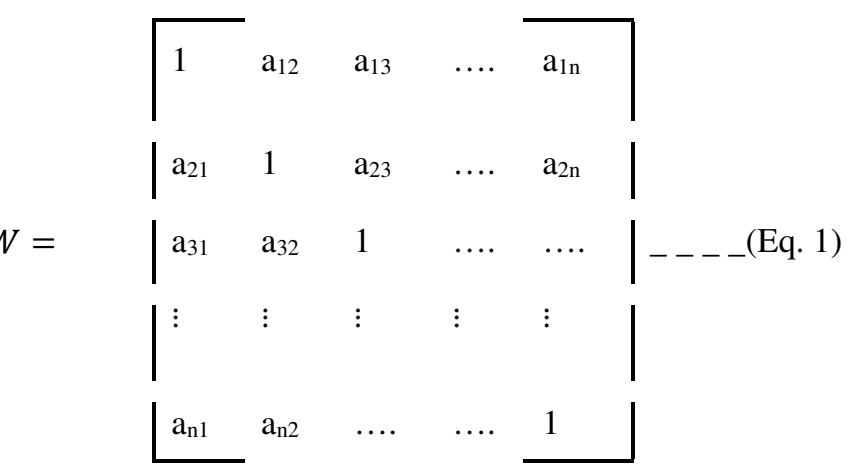

Where, $a_{i j}=\frac{\text { weight for attribute iweight for attribute i }}{\text { weight for attribute iweight for attribute } \mathrm{j}}$ 
Table 2: Pairwise comparison matrix for the selected thematic layers

\begin{tabular}{|c|c|c|c|c|c|c|c|c|}
\hline \multirow{2}{*}{$\begin{array}{l}\text { Thematic layers } \\
\text { Factors }\end{array}$} & \multicolumn{7}{|l|}{ Thematic layers } & \multirow[t]{2}{*}{ Normalized Weightage } \\
\hline & Lineament density & Geomorphology & Slope & Lithology & Soil & Drainage Density & $\begin{array}{l}\text { LUL } \\
\text { C }\end{array}$ & \\
\hline Lineament density & $6 / 6$ & $6 / 4$ & $6 / 4$ & $6 / 3$ & $6 / 3$ & $6 / 3$ & $6 / 2$ & 0.24 \\
\hline Geomorphology & $4 / 6$ & $4 / 4$ & $4 / 4$ & $4 / 3$ & $4 / 3$ & $4 / 3$ & $4 / 2$ & 0.16 \\
\hline Slope & $4 / 6$ & $4 / 4$ & $4 / 4$ & $4 / 3$ & $4 / 3$ & $4 / 3$ & $4 / 2$ & 0.16 \\
\hline Lithology & $3 / 6$ & $3 / 4$ & $3 / 4$ & $3 / 3$ & $3 / 3$ & $3 / 3$ & $3 / 2$ & 0.12 \\
\hline Soil & $3 / 6$ & $3 / 4$ & $3 / 4$ & $3 / 3$ & $3 / 3$ & $3 / 3$ & $3 / 2$ & 0.12 \\
\hline Drainage Density & $3 / 6$ & $3 / 4$ & $3 / 4$ & $3 / 3$ & $3 / 3$ & $3 / 3$ & $3 / 2$ & 0.12 \\
\hline LULC & $2 / 6$ & $2 / 4$ & $2 / 4$ & $2 / 3$ & $2 / 3$ & $2 / 3$ & $2 / 2$ & 0.08 \\
\hline Total & 4.17 & & & & & & & 1.00 \\
\hline
\end{tabular}


Normalization of the eigenvector of the largest eigenvalue of the pairwise comparison matrix computes relative importance of each element. Factors of the class that are expected to have high groundwater potential are given higher comparative weightage (Suganthi 2013).

The Consistency Ratio $(C R)$ is used to validate the consistency of a judgement. It is calculated by dividing the CI by the Random Consistency Index ( $R C I)$ and is represented algebraically in the equation below (Debasis 2020).

$C R=\frac{C i}{R i}----($ Eq. 2)

If the $C R$ value is less than 0.1 , the judgement value must be accepted; otherwise, a new comparison matrix must be constructed with fresh judgement value for all parameters until the $C R$ value is less than 0.1 . The following expression is used to calculate the $C I$ :

$C I=\frac{\lambda \max -n}{n-1}$ (Eq. 3)

where $\lambda \max$ is the maximum eigenvalue of " $W$ ", and the sequence of the square matrix is known as $n$. If $W$ is entirely constant, then $\lambda$ max equals $\mathrm{n}$, resulting in a zero CI. As the level of inconsistency rises, so does the value of $\lambda \max$ (Saaty 1980).

An overlay analysis was performed to determine overall weightages for all thematic layers. The potential zone for groundwater has been computed as follows: (Eq.4)

$214 \mathrm{GWPZ}=\sum($ Geomorphology rank X weight + Lithology rank X weight + Soil rank X weight + Lineament density rank $\mathrm{X}$ weight +Slope rank $\mathrm{X}$ weight + Drainage density rank $\mathrm{X}$ weight + Land use/land cover rank $\mathrm{X}$ weight)

Where $\mathrm{Fi}$ denotes the relative weighting of several geo-environmental parameters used to estimate groundwater potential, and Wi denotes the ranking of those elements (Achu 2020). The groundwater potential zone was created by dividing the study region into five classes: 1. Very good, 2. Good, 3. Medium, 4. Low, and 5. Very low.

\section{Dempster-Shafer model}

The theory was first introduced by Dempster (Dempster 1967) which was further developed by Shafer (1976), the DS model represents spatial integration of mathematical calculations (Sahereh et al. 2021). To use the DS model, weighting of the factors of the thematic layers are calculated, which offers the following probability layers: Belief, Disbelief, Uncertainty and Plausibility. All factors in the same course are united, to create a predicted underground water zone (Ali et al. 2017). If we divide each data layer into numerous classes, then the weight values of each class Belief (B) and Disbelief (D) are calculated as follows:

$B=\frac{W i}{p i}=\frac{\text { the percent of groundwater wells in the domain }}{\text { the percent of pixels in the domain }} \ldots . .(E q .5)$

$D=\frac{W \prime i}{p \prime i}=\frac{\text { the percent of groundwater out of the domain }}{\text { the percent of pixels out of the domain }} \quad \ldots . .(E q .6)$

228 The following equations are used to calculate Plausibility $(\mathrm{P})$ and Uncertainty (U):- 
$U=1-D-B \quad \ldots . .(E q .7)$

$P=1-D$

231 The groundwater potential map can be obtained using the following equation (Ali et al. 2017):

$G W P M=\left(\left[\right.\right.$ Altitude $\left.\_B e l\right]+[$ Slope Angle_Bel $]+\left[T W I \_B e l\right]+[$ Landuse_Bel $]+[$ Drainage Density_Bel $]+[$ Soil_Bel $]$ $+[$ Geomorphology_Bel] $+[$ Lineament Density_Bel] $+[$ Lithology_Bel] ...(Eq.9)

After preparing the following thematic layers: geomorphology, lithology, land use/land cover, soil type, altitude, slope, drainage density, TWI index and lineament density, class and weight values were calculated for each of these layers based on the actual groundwater well data (training data). According to the impressive factors which received grater belief (Bel) values have more efficiency on groundwater potential (Ali et al. 2017).

\section{Results and Discussion}

After preparing 9 data layers and classification of each layer into its factors, the weight values of each factor were calculated using the DS model based on actual groundwater well training data. In AHP model TWI and altitude were not considered as they have very less importance value, therefore only 7 data layers were considered for the analysis, characteristics of considered thematic layers according to its importance value have been depicted. Each layer has played an important role for determining the groundwater potential zones in the study area. The results obtained during the entire study have been discussed below;

\section{Geomorphology}

It is one of the important parameters widely considered for the delineation of the groundwater distribution in various landforms (Table 4). Higher water retention capability is denoted by river/water bodies and active floodplain which is considered as the best landform for groundwater potential. Alluvial plains deposited along with the river channel and flood plains are given highest rank while moderately dissected hills and valleys are given least ranking (1-5). The accumulated weightages for different geomorphological factors vary from 16 to 80 which indicates that factors with higher weightages influence groundwater potential.

North west side of the study area (Fig. 3 a) is covered by alluvial plains which indicate higher possibility of groundwater. In the DS model belief factor varies from 0 to 0.53 and disbelief 0.16 to 0.50 . Uncertainty rate varies from 0.12 to 0.51 . It reflects higher groundwater occurrence in low uncertainty zones which are classified as dams and reservoirs.

\section{Lineament Density}

As a result of faulting and jointing, lineaments relate to zones of enhanced porosity and permeability in hard rock area, hence they are very much important in groundwater investigations (Sreedevi et al. 2001; Koch \& Mather 1997). Higher groundwater potential is expected where the geological linear features are more intensive. The lineament trends North East and South West direction (Fig. 3 b). In the AHP model, the accumulated weightages varies from 24 to 120, since the layer received the highest weightages it is the most influencing factor for the groundwater potential delineation. Lineament density was classified into following intervals: $<0.03,0.03-0.10,0.10-0.18,0.18-0.28,0.28-0.48 \mathrm{~km} / \mathrm{km}^{2}$ as very low, low, medium, high, and very high respectively (Table 4) the maximum is $0.49 \mathrm{~km} / \mathrm{km}^{2}$. The highest lineament density interval received the top ranking. In the DS model the belief factors varies from 0.20 to 0.54 (Table 3) which is considered as one of the most influencing thematic layers, higher beliefs are present along with low lineament density. 


\section{Lithology}

Lithology controls soil porosity and water permeability and affects the specific storage of groundwater. Obtained weightage from the AHP comparison matrix is 0.12 and the overall weightages varies from 12 to 60 (Table 4). Several lithological features of the study area are marked in the map (Fig 3-c). Coarse grained porphyritic granite is dominant lithounits. Alluvium is characterized by silt, clay admixed with kankar. Gray sand, silt and clay are given the highest rank which constitute very low geographical coverage. In the DS model the belief factor varies from 0 to 0.64 (Table 3 ), higher in belief reflects high groundwater zone thus it is an important factor for groundwater potential mapping, Coarse Grained, Porphyritic Granite are associated with high beliefs $(0.64)$ rate.

\section{Slope}

278 Slope expresses the steepness of the ground surface or terrain. The nature of geological and geodynamic processes, surface runoff and infiltration rate are affected by slope. Here steep slopes imply low recharge because of the rapid flow of water while gentle slopes indicate higher groundwater recharge. The map reflects that the majority of the region in the study area constitutes slope ranging from 0 to 4 degree (Fig $3 \mathrm{~d}$ ). The calculated normalized weight for the slope from the AHP comparison matrix is 0.16 and overall weightages vary from 16 to 80 (Table 4). The slope is classified into the following intervals: 0-1.26, 1.26-2.40, 2.40-4.17, 4.17-10.74 and more than 10.74 degree. The high rank is given to the flat and gentle slope. The Northwest side of the study area has a gentle slope varying from 0 to 2 degrees while the North East side is characterized by 2 to 4 degrees. Steeper slopes are observed in the south west region of the study area which varies from 4 to 32 degrees (Fig $3 \mathrm{~d}$ ). The run-off is also coherent to the direction of steeper slope (NE-SW). In the DS model, belief rates vary from 0 to 0.64 , area under zero belief rate indicates unavailability of groundwater while higher belief associated with gentle slope indicates availability of groundwater. 

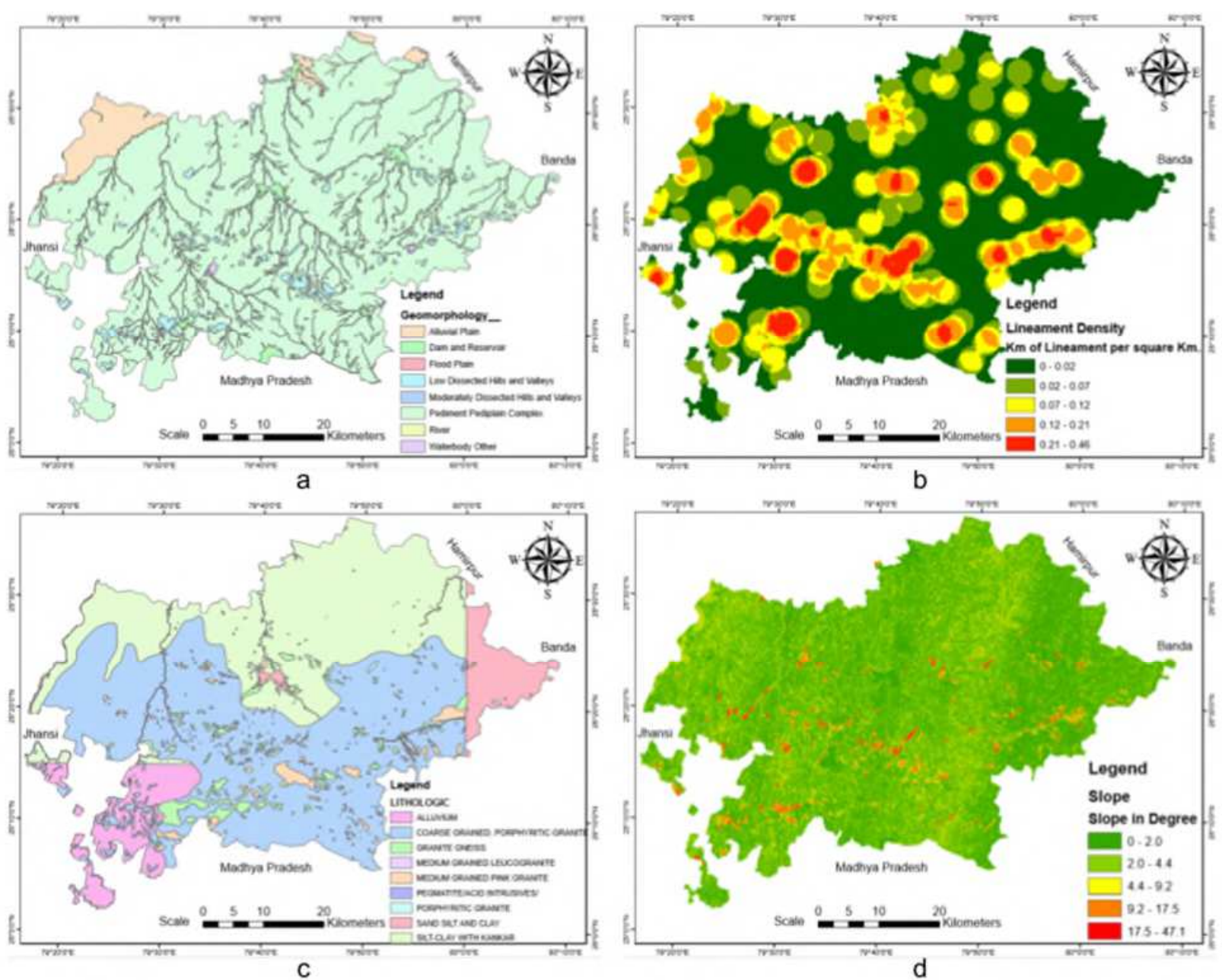

Fig. 3 Groundwater conditioning factors; (a) Geomorphology, (b) Lineament Density, (c) Lithology, (d) Slope, (e) Soil, (f) Land use/land cover, (g) Topographic Wetness Index, (h)Drainage Density, (i) Pie-Chart of LULC, (j) Altitude

\section{Soil}

Soils surface condition influences the infiltration as well as transmission rate. Soil varies in its composition and has different slopes and textures. Loamy soil as observed in the study area is formed with the mixture of silt, clay and sand. These soils are considered to be fertile and easy to work with, they also provide good drainage. It is further classified as sandy or clay loamy depending on their predominant compositions. These soils are highly permeable which contain good amount of groundwater. The calculated normalized weight for the soil from the comparison matrix is 0.12 and the overall weightages vary from 24 to 48 (Table 4), low weightages indicate less influence in delineation of groundwater zones. Fine smectitic soil was given high ranking as 4 and deep loamy soil was given lowest ranking as 2. Different types of soil have been depicted in Fig $3 \mathrm{e}$. In the DS model belief rate varies from 0.31 to 0.53 (Table (0.42 to 0.50$)$.

\section{Land use/Land cover (LULC)}

305 The LULC map (Fig 3-f) provides information about forests, built up, impervious surfaces, agriculture, and water 
bodies etc. The given pie chart (Fig. 3 i) illustrates land cover in the Mahoba district. Agriculture accounts for $62 \%$ of the total land where commercial activities like mines cover less than $1 \%$. Approximately $16.8 \%$ of the district land is covered by wetland followed by barren land i.e. 9.3\%. Water Bodies in the district is less than one percentage of the total land cover. Since, the district is densely populated the built up area accounts for more than vegetation and water bodies, i.e. 6.9\%. The calculated weight from the AHP comparison matrix is 0.08 and the overall weightages vary from 8 to 40 (Table 8.0). Water bodies and forest cover were given high ranking as 5 and 4 respectively, built-up area was given low weight as 1 . In the DS model the belief rate varies from 0 to 0.67 while uncertainty varies from 0.06 to 0.51 (Table 3 ). Here agriculture is associated with higher belief $(0.67)$ indicating occurrence of groundwater.
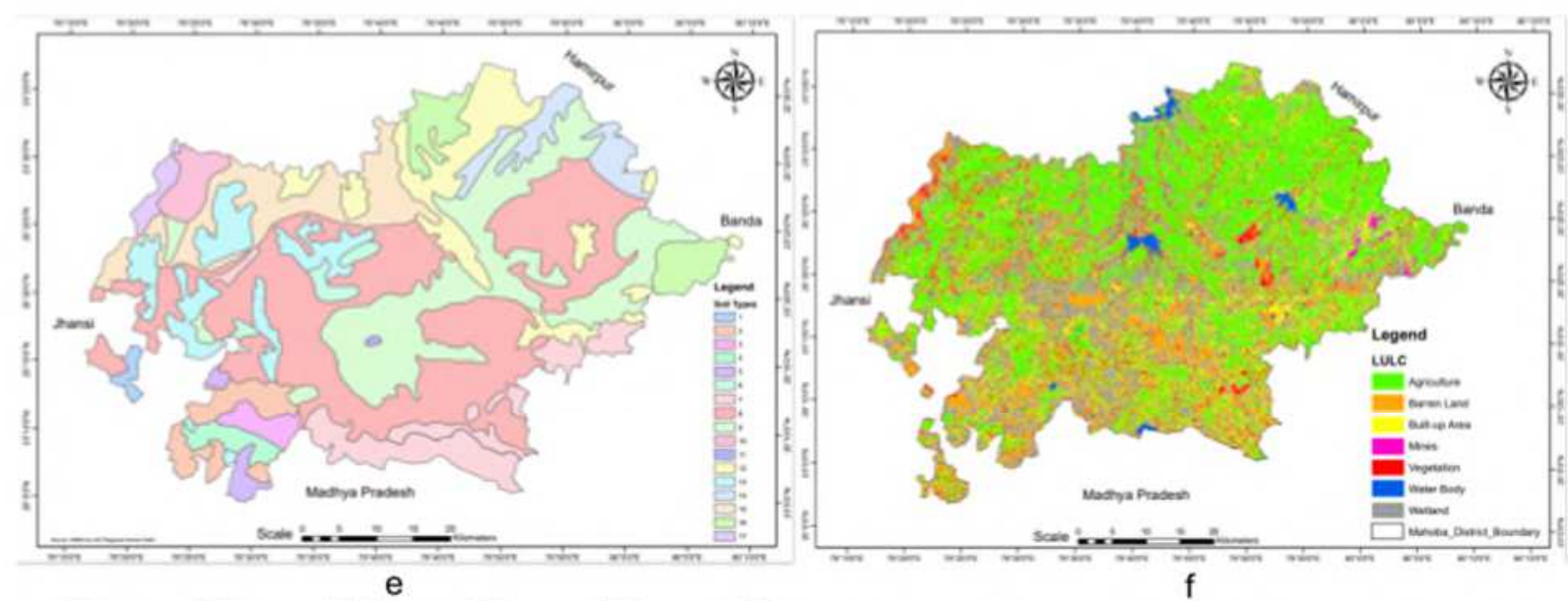

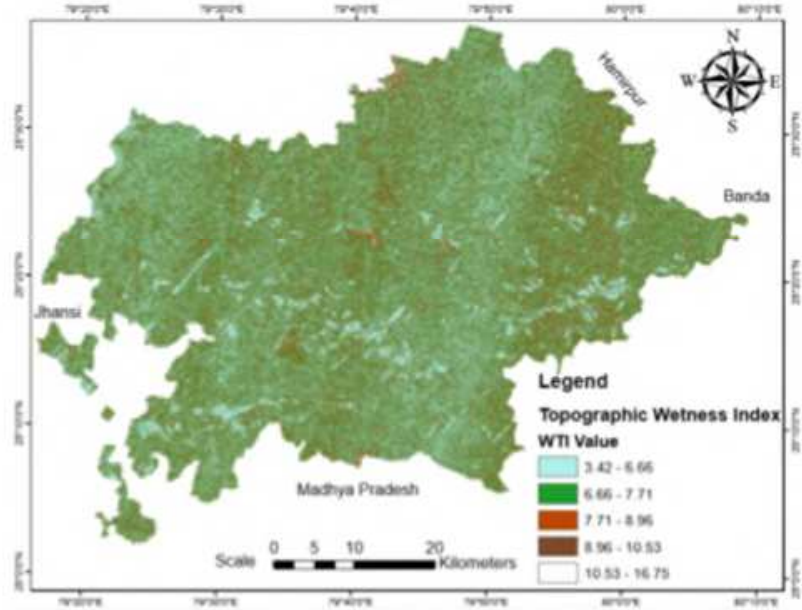

g

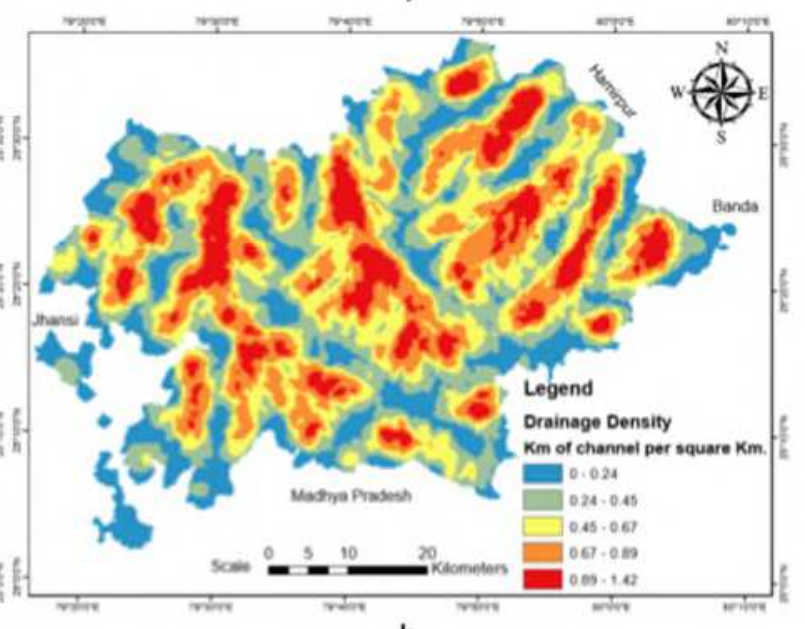

h

Fig 3 (continued)

\section{Drainage Density}

Drainage density, defined as the total length of drainage channels per unit area, helps to evaluate and understand the characteristics of runoff and groundwater infiltration (Suganthi 2013). The region was classified (Fig 3-h) as very high, high, medium, low and very low, which are ranked as 1,2,3,4 and 5, respectively. The calculated normalized weight from the AHP comparison matrix was 0.12, overall weightage varies from 12 to 60 (Table 4). In the study area, high runoff density indicates high surface runoff and low infiltration rate, while low and very low runoff density indicates low runoff and high infiltration rate. The percolation of rainwater takes place in low drainage density areas therefore occurrence of groundwater is estimated as high rank for the same. In the DS model belief rates varies from 0.42 to 0.51 and uncertainty rates varies from 0 to 0.07 (Table 3), which indicate low uncertainty rate for presence of 
groundwater.
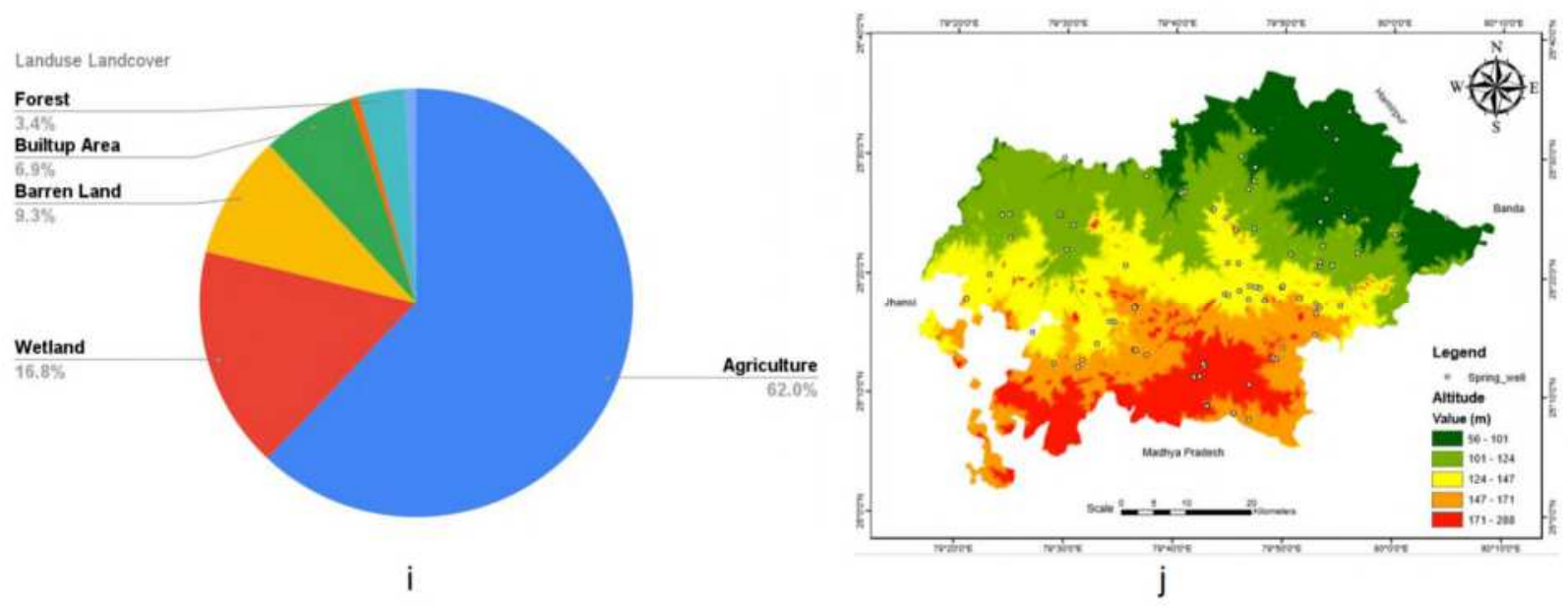

Fig 3 (Continued)

Topographic Wetness Index

Topographic Wetness Index (TWI) is one of the important factors considered to study the groundwater potential zone, it describes the relationship between the diversion of the water accumulated in the site part and the gravity that pushes the water according to the slope. The following equation is used for the calculation of TWI factor (Moore et al. 1991):

$$
T W I=\ln (\alpha / \tan \beta)
$$

Where $\alpha$ is the contributing upslope area and $\beta$ is the topographic gradient at the same point in the terrain. In the present study TWI map was prepared using a digital elevation model of CartoDEM data. The map is classified into five categories as illustrated in the (Fig $3 \mathrm{~g}$ ). The lower wetness index value varies from 3.42 to 6.66 while high values vary from 10.53 to 16.75. According to Moghaddam et al. (2015), Rodhe and Seibert (1999) and Sahereh et al. (2021) thematic layers representing topographic factors play a conclusive role in the estimation of the groundwater flow zones. Several researchers (Pourghasemi et al. 2014; Falah et al. 2016, Sahereh et al. 2021; Pourtaghi et al. 2014) have used Topographic Wetness Index (TWI) for groundwater potentiality mapping. This thematic layer was not considered as an effective factor for the groundwater potential under AHP model of investigation.

\section{Elevation}

The relationship between groundwater occurrence and altitude, High altitude reduces the ability to recharge groundwater, thereby reducing groundwater potential. Elevation map was prepared using CartoDEM data which has spatial resolution of $30 \mathrm{~m}$. The map altitude value varies from $56 \mathrm{~m}$ to $288 \mathrm{~m}$. The map is classified into five categories as shown in the fig. $3-\mathrm{j}$. 
Table 3 Spatial relationship between each effective factor and borewell locations of the DS model

\begin{tabular}{|c|c|c|c|c|c|c|c|c|}
\hline Class & Factors & No of pixels & No of Borewell & Bel & Dis & Unc & Pls & SI \\
\hline \multirow{9}{*}{ Lithology } & Alluvium & 3113 & 5 & 0.48 & 0.49 & 0.03 & 0.51 & -0.01 \\
\hline & $\begin{array}{l}\text { Coarse Grained, Porphyritic } \\
\text { Granite }\end{array}$ & 23192 & 49 & 0.64 & 0.31 & 0.05 & 0.69 & 0.27 \\
\hline & Granite Gneiss & 1399 & 2 & 0.43 & 0.49 & 0.08 & 0.51 & -0.12 \\
\hline & Medium Grained Leucogranite & 26 & 0 & 0.00 & 0.49 & 0.51 & 0.51 & - \\
\hline & Medium Grained Pink Granite & 962 & 0 & 0.00 & 0.50 & 0.50 & 0.50 & - \\
\hline & $\begin{array}{l}\text { Pegmatite/Acid } \\
\text { Intrusives/Quartzofeldspathic } \\
\text { Veins }\end{array}$ & 17 & 0 & 0.00 & 0.49 & 0.51 & 0.51 & - \\
\hline & Porphyritic Granite & 98 & 0 & 0.00 & 0.49 & 0.51 & 0.51 & - \\
\hline & Sand Silt And Clay & 2843 & 3 & 0.32 & 0.50 & 0.18 & 0.50 & -0.43 \\
\hline & Silt-clay With Kankar & 15939 & 20 & 0.38 & 0.54 & 0.08 & 0.46 & -0.25 \\
\hline \multirow{5}{*}{ Soil } & Deep Fine Smectitic Soil & 1042 & 1 & 0.31 & 0.49 & 0.20 & 0.51 & -0.47 \\
\hline & Deep Fine Soil & 9914 & 14 & 0.45 & 0.50 & 0.05 & 0.50 & -0.08 \\
\hline & Deep Loamy Soil & 32033 & 53 & 0.53 & 0.42 & 0.05 & 0.58 & 0.08 \\
\hline & Shallow Loamy Soil & 1530 & 2 & 0.42 & 0.49 & 0.09 & 0.51 & -0.16 \\
\hline & Rock Outcrops & 5758 & 7 & 0.39 & 0.50 & 0.11 & 0.50 & -0.23 \\
\hline \multirow{7}{*}{ LULC } & Water & 1033810 & 0 & 0.00 & 0.50 & 0.50 & 0.50 & - \\
\hline & BuiltUp Area & 1181778 & 2 & 0.29 & 0.49 & 0.22 & 0.51 & -0.53 \\
\hline & Agriculture & 18042970 & 58 & 0.67 & 0.27 & 0.06 & 0.73 & 0.31 \\
\hline & Barren Land & 10748400 & 14 & 0.27 & 0.59 & 0.14 & 0.41 & -0.59 \\
\hline & Mines & 164179 & 0 & 0.00 & 0.49 & 0.51 & 0.51 & - \\
\hline & Forests & 1614137 & 3 & 0.39 & 0.49 & 0.12 & 0.51 & -0.23 \\
\hline & Wetland & 1783751 & 0 & 0.00 & 0.50 & 0.50 & 0.50 & - \\
\hline WTI & $3.42-6.66$ & 882728 & 22 & 0.53 & 0.47 & 0.00 & 0.53 & 0.08 \\
\hline
\end{tabular}




\begin{tabular}{|c|c|c|c|c|c|c|c|c|}
\hline & $6.67-7.71$ & 1237633 & 28 & 0.48 & 0.49 & 0.03 & 0.51 & -0.02 \\
\hline & 7.72-8.96 & 703111 & 15 & 0.45 & 0.50 & 0.05 & 0.50 & -0.08 \\
\hline & $8.97-10.53$ & 312639 & 7 & 0.47 & 0.49 & 0.04 & 0.51 & -0.03 \\
\hline & $10.54-16.75$ & 208840 & 5 & 0.51 & 0.49 & 0.01 & 0.51 & 0.04 \\
\hline \multirow{5}{*}{ Drainage Density } & $0-0.245$ & 8639 & 16 & 0.51 & 0.48 & 0.00 & 0.52 & 0.05 \\
\hline & $0.245-0.457$ & 10930 & 20 & 0.51 & 0.48 & 0.01 & 0.52 & 0.04 \\
\hline & $0.458-0.670$ & 10457 & 16 & 0.42 & 0.51 & 0.07 & 0.49 & -0.14 \\
\hline & $0.671-0.898$ & 8957 & 16 & 0.50 & 0.49 & 0.02 & 0.51 & 0.02 \\
\hline & $0.899-1.423$ & 4842 & 9 & 0.52 & 0.48 & 0.00 & 0.52 & 0.06 \\
\hline \multirow{5}{*}{ Slope } & $0-2.0$ & 1750045 & 53 & 0.64 & 0.32 & 0.04 & 0.68 & 0.27 \\
\hline & $2.0-4.4$ & 1162370 & 16 & 0.29 & 0.59 & 0.12 & 0.41 & -0.51 \\
\hline & $4.4-9.2$ & 248988 & 6 & 0.51 & 0.49 & 0.00 & 0.51 & 0.05 \\
\hline & $9.2-17.5$ & 111597 & 2 & 0.38 & 0.49 & 0.13 & 0.51 & -0.25 \\
\hline & $17.5-47.1$ & 71981 & 0 & 0.00 & 0.50 & 0.50 & 0.50 & - \\
\hline \multirow{5}{*}{ Altitude } & $56-101$ & 704476 & 15 & 0.45 & 0.50 & 0.05 & 0.50 & -0.07 \\
\hline & $101-124$ & 913834 & 21 & 0.49 & 0.49 & 0.02 & 0.51 & 0.00 \\
\hline & $124-147$ & 746043 & 18 & 0.51 & 0.48 & 0.01 & 0.52 & 0.05 \\
\hline & $147-171$ & 605826 & 14 & 0.49 & 0.49 & 0.02 & 0.51 & 0.01 \\
\hline & $171-288$ & 390435 & 9 & 0.49 & 0.49 & 0.02 & 0.51 & 0.01 \\
\hline \multirow{3}{*}{ Lineament Density } & $0-0.023785631$ & 23078 & 45 & 0.54 & 0.43 & 0.03 & 0.57 & 0.10 \\
\hline & $0.023785631-0.071356893$ & 6163 & 10 & 0.45 & 0.49 & 0.06 & 0.51 & -0.08 \\
\hline & $0.071356893-0.128076474$ & 6610 & 11 & 0.46 & 0.49 & 0.05 & 0.51 & -0.05 \\
\hline
\end{tabular}




\begin{tabular}{|l|l|l|l|l|l|l|l|l|}
\hline \multirow{5}{*}{} & $0.128076474-0.214070678$ & 5143 & 9 & 0.49 & 0.49 & 0.03 & 0.51 & 0.00 \\
\cline { 2 - 8 } & $0.214070678-0.466564298$ & 2831 & 2 & 0.20 & 0.51 & 0.30 & 0.49 & -0.91 \\
\hline \multirow{5}{*}{ Geomorphology } & Alluvial Plain & 1531076 & 1 & 0.13 & 0.48 & 0.38 & 0.52 & -1.29 \\
\cline { 2 - 8 } & Dam and Reservoir & 528854 & 1 & 0.39 & 0.49 & 0.12 & 0.51 & -0.22 \\
\cline { 2 - 9 } & Flood Plain & 8158 & 0 & 0.00 & 0.49 & 0.51 & 0.51 & - \\
\cline { 2 - 9 } & Low Dissected Hills and Valleys & 1047072 & 1 & 0.20 & 0.50 & 0.31 & 0.50 & -0.91 \\
\cline { 2 - 9 } & $\begin{array}{l}\text { Moderately Dissected Hills and } \\
\text { Valleys }\end{array}$ & 21921 & 0 & 0.00 & 0.49 & 0.51 & 0.51 & - \\
\cline { 2 - 9 } & Pediment Pediplain Complex & 28727610 & 74 & 0.53 & 0.16 & 0.31 & 0.84 & 0.09 \\
\cline { 2 - 9 } & River & 598207 & 0 & 0.00 & 0.50 & 0.50 & 0.50 & - \\
\cline { 2 - 8 } & Waterbodies Other & 83171 & 0 & 0.00 & 0.49 & 0.51 & 0.51 & - \\
\hline
\end{tabular}


Table 3 shows the results of the spatial relationship between the existence of groundwater and the impressive factors using the Dempster-Shafer theory (doubt, belief, reasonableness and uncertainty). The groundwater potential map Fig (5-b) was prepared using equation(9), the integrated result indicates that enormous groundwater potential was found for the region having greater values of belief and small values of disbelief for the incidence. The belief values vary from 1.79 to 4.56 (Fig 4-a) while Disbelief varies from 3.69 to 4.75 (Fig 4-b). The uncertainty graph(Figure 4.-c) illustrates the lack of information that provides real evidence of the spring incidence. High levels of uncertainty appear in areas with low levels of belief. The plausibility map (Fig 4-d) represents a higher degree where both uncertainty and belief are higher.
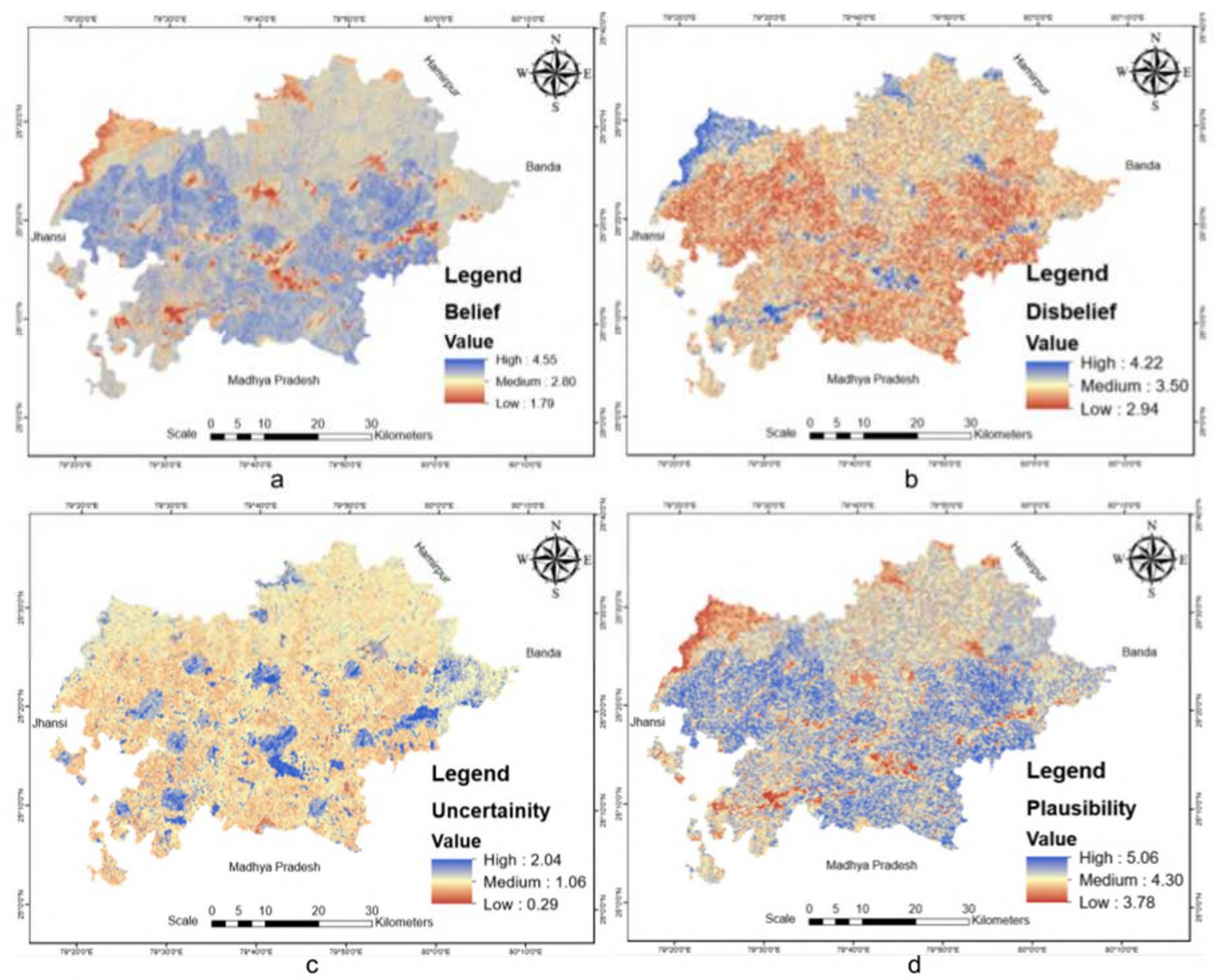

Fig. 4 Integrated results of DS model (a) Belief, (b) Disbelief, (c) Uncertainty, and (d) Plausibility. 
361 Table 4: Factors of used thematic layers (class) and obtained accumulated weightages through AHP model.

\begin{tabular}{|c|c|c|c|c|}
\hline Class & Factor & $\%$ Weightage & Rank & Accumulated Weightage \\
\hline \multirow{8}{*}{ Geomorphology } & Alluvial Plain & \multirow{8}{*}{16} & 5 & 80 \\
\hline & Dam and Reservoir & & 5 & 80 \\
\hline & Flood Plain & & 5 & 80 \\
\hline & Low Dissected Hills and Valleys & & 2 & 32 \\
\hline & Moderately Dissected Hills and Valleys & & 1 & 16 \\
\hline & Pediment Pediplain Complex & & 2 & 32 \\
\hline & Waterbodies-Other & & 4 & 64 \\
\hline & Waterbody - River & & 5 & 80 \\
\hline \multirow{5}{*}{ Lineament density } & Very High & \multirow{5}{*}{24} & 5 & 120 \\
\hline & High & & 4 & 96 \\
\hline & Medium & & 3 & 72 \\
\hline & Low & & 2 & 48 \\
\hline & Very Low & & 1 & 24 \\
\hline \multirow{4}{*}{ Lithology } & $\begin{array}{l}\text { Silt-clay With Kankar \& Quartzo- } \\
\text { feldspathic Sand }\end{array}$ & \multirow{4}{*}{12} & 3 & 36 \\
\hline & Quartzite & & 4 & 48 \\
\hline & Quartz Sericite Schist & & 4 & 48 \\
\hline & Quartz-biotite Schist & & 4 & 48 \\
\hline
\end{tabular}




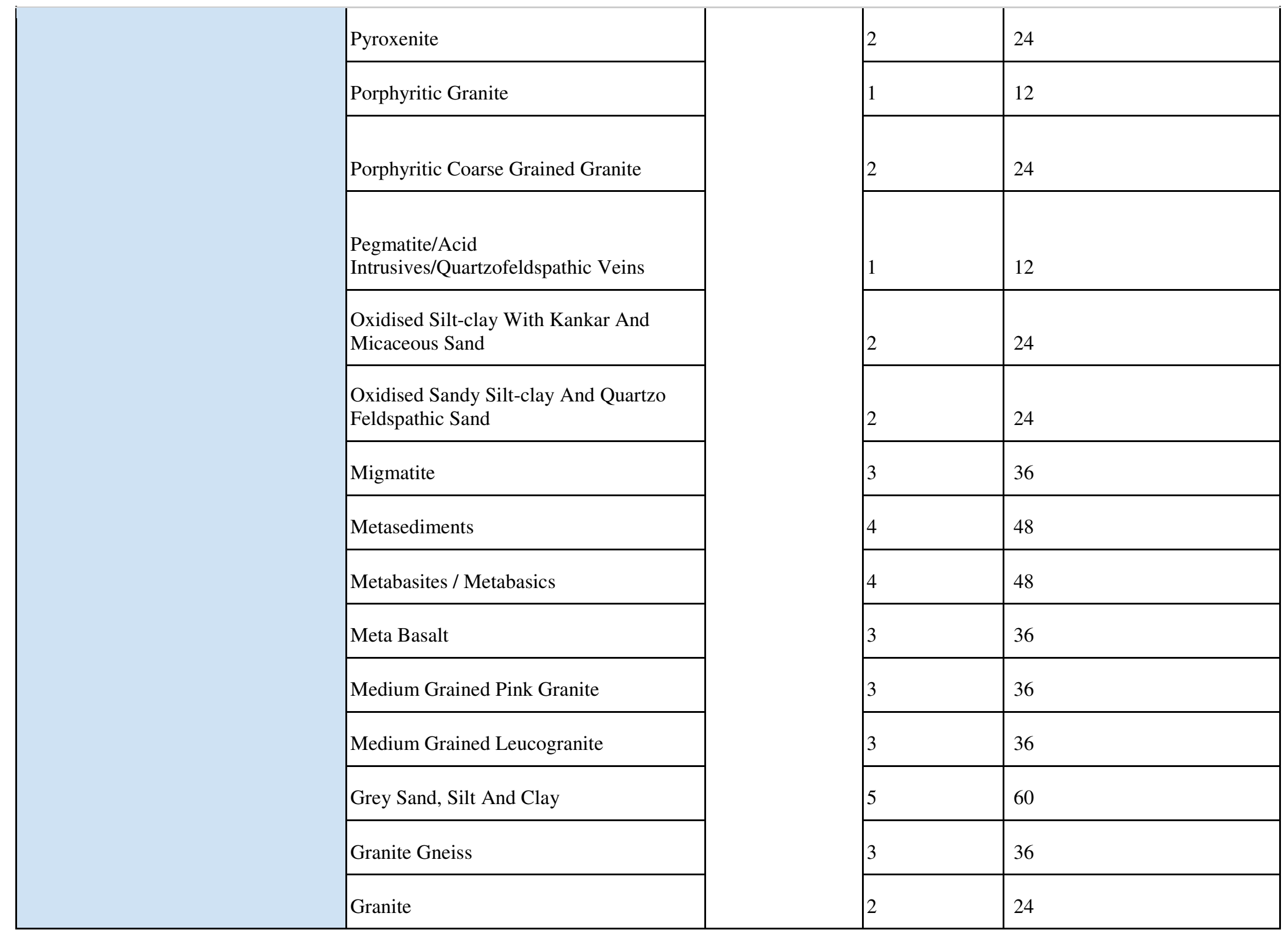




\begin{tabular}{|c|c|c|c|c|}
\hline & Fine Grained LeucoGranite & & 3 & 36 \\
\hline & Fine Grained LeucoGranite & & 3 & 36 \\
\hline & Dolerite & & 4 & 48 \\
\hline & Coarse Grained, Porphyritic Granite & & 2 & 24 \\
\hline & Chlorite Schist & & 1 & 12 \\
\hline & Augen Gneiss & & 4 & 48 \\
\hline & Amphibolite & & 3 & 36 \\
\hline & Alluvium & & 4 & 48 \\
\hline \multirow{5}{*}{ Slope } & $0-1$ & \multirow{5}{*}{16} & 5 & 80 \\
\hline & $1-2$ & & 4 & 64 \\
\hline & $2-3$ & & 3 & 48 \\
\hline & $3-5$ & & 2 & 32 \\
\hline & $>5$ & & 1 & 16 \\
\hline \multirow{4}{*}{ Soil } & Fine Smectitic Soil & \multirow{4}{*}{12} & 4 & 48 \\
\hline & Shallow Loamy Soil & & 3 & 36 \\
\hline & Smectitic Soil & & 3 & 36 \\
\hline & Rock Loamy Soil & & 3 & 36 \\
\hline
\end{tabular}




\begin{tabular}{|c|c|c|c|c|}
\hline & Deep Loamy Soil & & 2 & 24 \\
\hline \multirow{7}{*}{ Land Use Land Cover (LULC) } & Agriculture & \multirow{7}{*}{8} & 3 & 24 \\
\hline & Barren Land & & 2 & 16 \\
\hline & Builtup Area & & 1 & 8 \\
\hline & Mines & & 3 & 24 \\
\hline & Vegetation & & 4 & 32 \\
\hline & Water & & 5 & 40 \\
\hline & Wetland & & 3 & 24 \\
\hline \multirow{5}{*}{ Drainage Density } & Very High & \multirow{5}{*}{12} & 1 & 12 \\
\hline & High & & 2 & 24 \\
\hline & Medium & & 3 & 36 \\
\hline & Low & & 4 & 48 \\
\hline & Very Low & & 5 & 60 \\
\hline
\end{tabular}




\section{Groundwater Potential Zones}

The groundwater potential maps were prepared using the relative importance of several thematic layers, factors influencing these thematic layers was divided into several categories for estimation of groundwater potential zone. Thematic layers viz.: geomorphology, lineament density, lithology, slope, soil, LULC, drainage density, altitude and Topographic Wetness Index were used under overlay analysis. The map shown in fig 5-a represents groundwater potential zones using AHP model and fig 5-b represents groundwater potential zones using DS model. Both the maps were classified into very high, high, moderate, low and very low groundwater zones.

In AHP model groundwater potential zone map, it is evident that the North -West side of the study area (Fig. 5-a) has high groundwater potential which is classified as very high zone, this zone has an area of $206.19 \mathrm{~km}^{2}$. High groundwater zones constitute an area of $919.31 \mathrm{~km}^{2}$ and followed by medium zone of $1290.25 \mathrm{~km}^{2}$ which cover the majority of the study area. Low zone has an area of $454.69 \mathrm{~km}^{2}$ while very low zone $12.15 \mathrm{~km}^{2}$.

In the DS model (Fig. 5-b), the south west and south east side of the study has high and very high groundwater potential zones which cover $34 \%$ and $17 \%$ (Table 5) of the study area respectively. North east side of the study area is classified as poor and very poor groundwater potential zones. The similar trend is also observed in the AHP model. The AHP model supplement the objectivity while the DS model supports subjectivity.

All the channels of watersheds contain a good amount of groundwater relative to the other region of study area. High zone regions are influenced by streams channels. Jaitpur and Panwari blocks of the Mahoba district have high groundwater potential relative to Charkhari and Kabrai blocks.

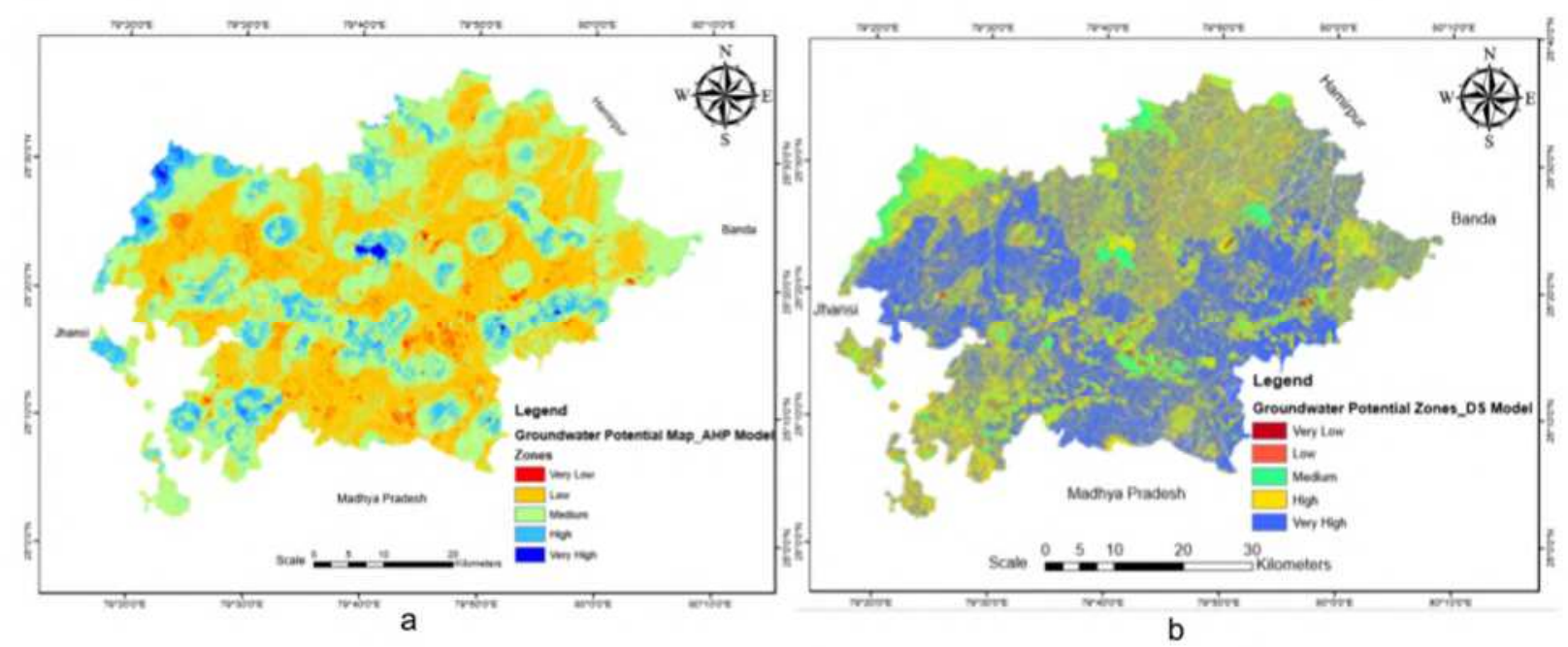

Fig. 5 Groundwater Potential Zones Maps a) Groundwater potential zones using AHP model, and b) Groundwater Potential zones using DS model

Table 5 Percentage of area under different groundwater potential zones
\begin{tabular}{|l|r|l|l|}
\hline \multicolumn{2}{|c|}{ DS Model } & & \multicolumn{2}{c|}{ AHP Model } \\
\hline Groundwater Potential Zones & $\%$ Area & Groundwater Potential Zones & $\%$ Area \\
\hline Very Poor & 4.19 & Very Poor & 0.42 \\
\hline
\end{tabular}




\begin{tabular}{|l|r|l|r|}
\hline Poor & 14.80 & Poor & 15.77 \\
\hline Medium & 29.07 & Medium & 44.76 \\
\hline High & 34.4 & High & 31.89 \\
\hline Very High & 17.54 & Very High & 7.15 \\
\hline
\end{tabular}

\section{Groundwater Quality}

The groundwater is contaminated with fluoride in pockets under granite and alkali granite, particularly in the extreme southern region of the study area. Weathering is responsible for leaching of fluoride into the groundwater. It has deteriorated because of geogenic activities. In the northern part of the study area, negligible thickness of overburden (weathered rock and loose soil) are present. Therefore, the concentration of TDS, fluoride and bicarbonate in groundwater increases due to poor fluxing of groundwater. In the central and northern part of the study area concentration of the nitrate in the groundwater has increased due to anthropogenic activities such as unlined septic tanks, unplanned sewerage systems. Additionally, terrain under granite-gneiss contains fixed atmospheric nitrogen which gets added to the soil through bacteria present in plants and soil, natural lighting. Nitrification also occurs due to ammonification of animal waste and plants. Hydro-chemical facies reveal that the nature of groundwater is $\mathrm{Na}+-$ $\mathrm{Cl}-$, mixed $\mathrm{Ca} 2+-\mathrm{Mg} 2+-\mathrm{Cl}-$ and $\mathrm{Ca} 2+-\mathrm{HCO}-3$ type the study area. (Ram et al. 2021)

\section{Validation}

According to Tehrany et al. (2013), in the ROC curve sensitivity is plotted against true positive and true negative value of groundwater occurrence and the Area Under the Curve (AUC) shows the distribution performance of the models. Here AUC equals to zero indicates a non-informative model while perfect condition represents AUC equals to one. The AUC for the AHP model is $76 \%$ while it is $79 \%$ for the DS model, therefore the DS model is more accurate then the AHP model as per ROC curve(Fig. 6). This is because the weight value of TWI and altitude data layers has influenced belief rate, while removing the same results in lower accuracy. The accuracy of the delineated groundwater potential zones in different watersheds under the study area was validated by analysing the bivariate relationship between the groundwater potential zones and the bore well yield data. 16 borewell data were used to validate the results. The validation result indicates that borewells having high discharge (>1500 liter/h) lie in high and very high groundwater potential zones. Whereas discharge of borewells ( $<1500$ liter/hour) lies in moderate and low groundwater

\section{Sensitivity analysis of the thematic layers}

416 In AHP model Sensitivity analysis revealed that the majority of the area has overall weightages varying from 224 to 332 (Fig 7) which is medium and low groundwater zones. The maximum weightage is noted as 456 and minimum as

Table 5 Statistical analysis of single parameter sensitivity analysis of AHP model weightages

\begin{tabular}{|l|l|l|l|l|}
\hline Parameters & Minimum & Maximum & Mean & Standard deviation \\
\hline Lineament density & 24 & 120 & 72.00 & 37.95 \\
\hline
\end{tabular}




\begin{tabular}{|l|l|l|l|l|}
\hline Geomorphology & 16 & 80 & 58.00 & 26.96 \\
\hline Slope & 16 & 80 & 48.00 & 25.30 \\
\hline Lithology & 12 & 60 & 35.11 & 12.86 \\
\hline Soil & 12 & 48 & 36.00 & 8.49 \\
\hline Drainage Density & 12 & 60 & 24.00 & 18.97 \\
\hline LULC & 8 & 40 & 24.00 & 24.00 \\
\hline
\end{tabular}

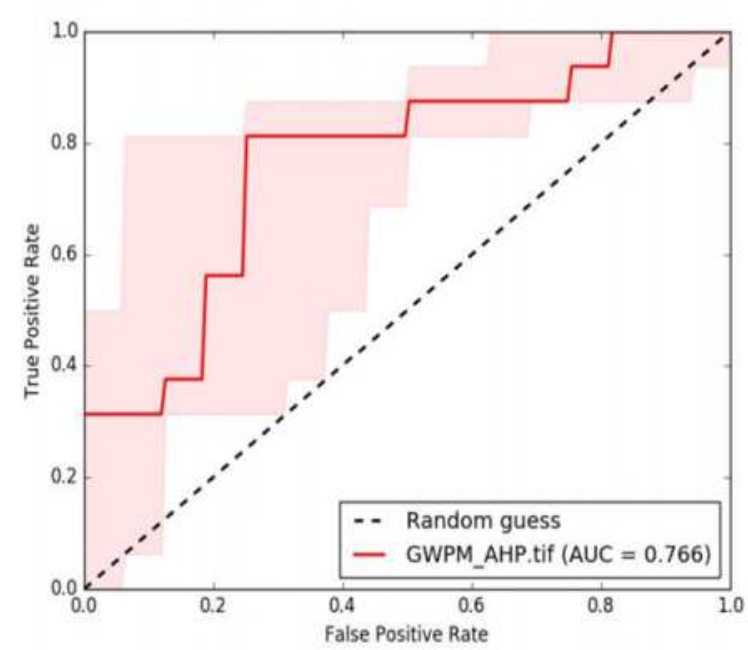

a

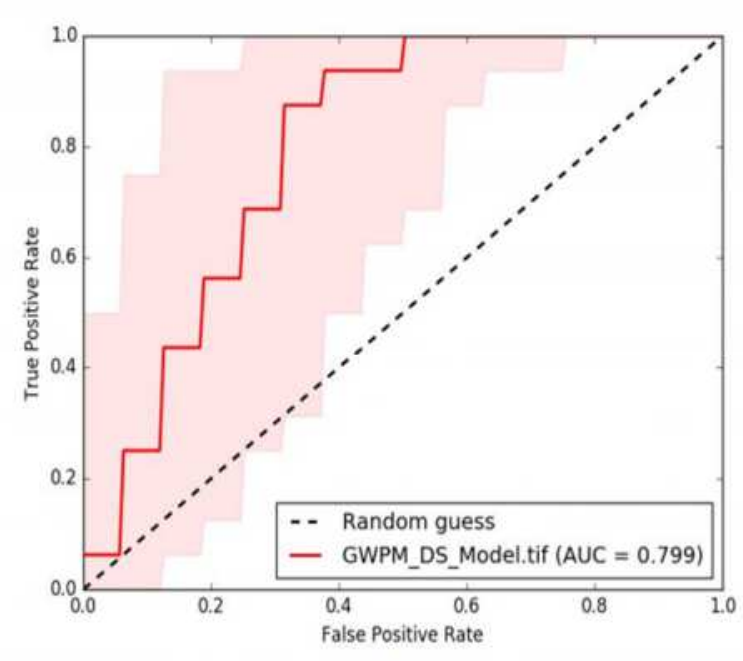

b 

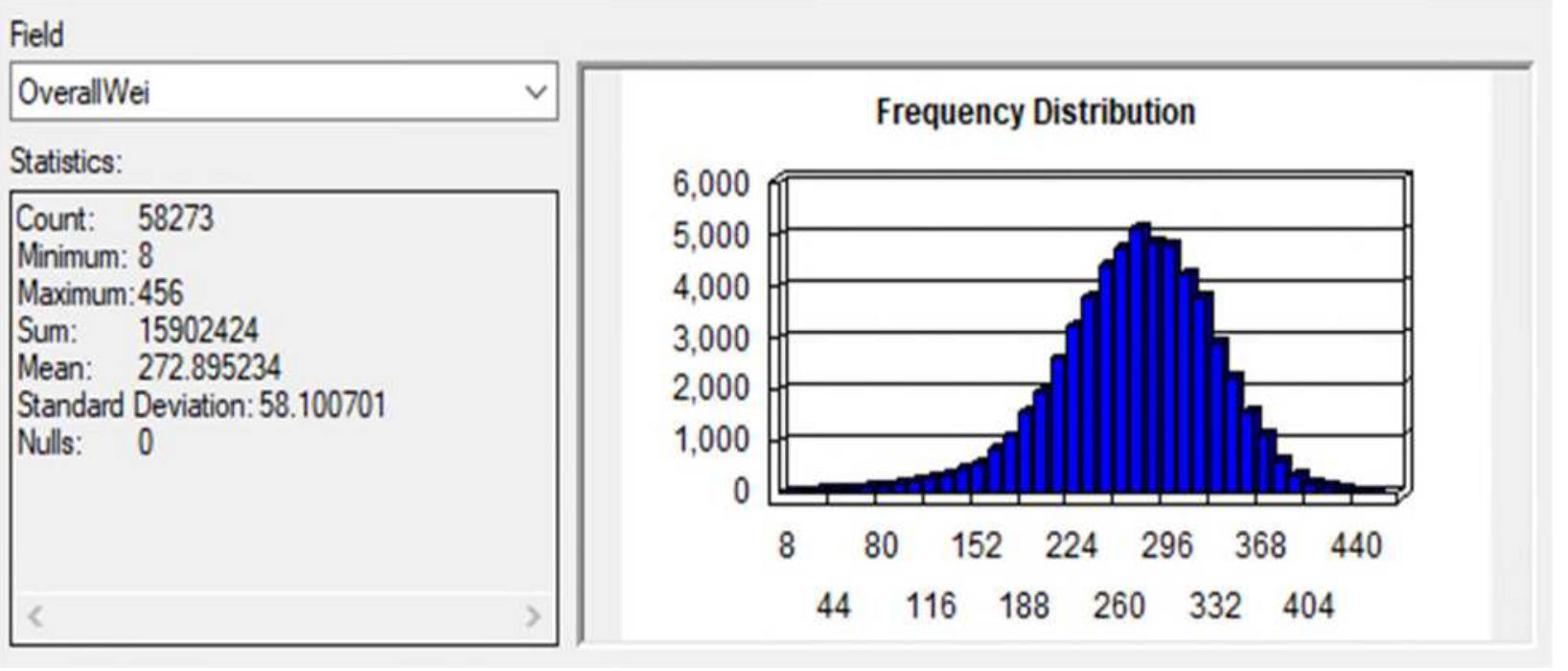

Fig. 7 Frequency distribution of overall weightages

\section{Limitations}

The accuracy obtained through both the models is more than $75 \%$ and limitation lies with pixel size of a particular class. Because different classes constitute different pixel sizes, therefore belief and importance rate may differ slightly from what was taken in consideration for the delineation of the groundwater potential maps.

\section{Conclusion}

The groundwater potential zones (GWPZs) of Mahoba District of Uttar Pradesh, were delineated by an integrated approach using AHP and Dempster Shafer model based on remote sensing and GIS. Several hydrogeological factors of the watersheds, such as geomorphology, drainage density, lineament density, lithology, slope, land use/land cover, soil, altitude and Topographic Wetness Index were used for multi-criteria decision analysis (MCDA) which was again equated in ArcMap using weighteges generated through the AHP model and Belief, Disbelief, Uncertainty, and Plausibility through DS model.

In the AHP model lineament density was considered as the most influencing criteria and was given high weight for groundwater potential zone mapping. Normalize weightages for factors considered in the AHP comparison matrix 
was calculated as follows: geomorphology (0.38), lineament density (0.19), lithology (0.13), slope (0.10), soil (0.08), LULC (0.06) and drainage density (0.05), overall weightages calculated while assigning ranks for factors of a thematic layer through overlay analysis was performed for the delineation of the groundwater potential zone.

The north-west side of the study area was found to be a very high groundwater zone while the northeast and southeast side of the region was low groundwater zone. The very high groundwater zone constitutes an area of $206.92 \mathrm{~km}^{2}$ while the low groundwater zone has an area of only $54.28 \mathrm{~km}^{2}$. The study area is dominated by the medium groundwater zone which consists of a total area of $1587.18 \mathrm{~km}^{2}$. In the DS model, Belief, Disbelief, Uncertainty, and Plausibility was equated using borewell locations and occurrence of groundwater factors of several thematic layers, the groundwater potential map illustrates that the south west and south east side of the study has high and very high groundwater potential zones, it is also found that streams and canals belong to the very high groundwater zone. The study has been validated using field data pertaining to yield wells. The receptor operating curve (ROC) method was used to validate the result, which showed the DS model is more accurate than the AHP model.

\section{Ethical Approval}

(Not applicable)

\section{Consent to Participate}

All the authors give their consent to participate.

\section{Consent to Publish}

All the author gives their consent to publish.

\section{Authors Contribution}

Hemant Kumar Pandey has contributed in introduction and methodology section, Vishal Kumar Singh has contributed in numerical analysis and software application while Sudhir Kumar Singh has contributed in result and discussion section of the manuscript.

\section{Availability of Data and Materials}

The data will be made available on request.

\section{References}

A L Achu, Jobin Thomas, Rajesh Reghunath, Multi-criteria decision analysis for delineation of groundwater potential zones in a tropical river basin using remote sensing, GIS and analytical hierarchy process (AHP), Groundwater for Sustainable Development, Volume 10, 2020, 100365, ISSN 2352-801X, https://doi.org/10.1016/j.gsd.2020.100365

A. Doke, S. D. Pardeshi, S.S. Pardeshi, S. Das, Identification of morphogentic regions and respective geomorphic processes: a GIS approach, Arabian J. Geosci., 11(2018), pp. 1-13, 10.1007/s12517-017-3358-5

Adiat, K.A.N., Nawawi, M.N.M., Abdullah, K., 2012. Assessing the accuracy of GIS-based elementary multi criteria decision analysis as a spatial prediction tool—a case of predicting potential zones of sustainable groundwater resources. J. Hydrol. 440, 75-89

Adimalla, N. Controlling factors and mechanism of groundwater quality variation in semiarid region of South India: an approach of water quality index (WQI) and health risk assessment (HRA). Environ Geochem Health 42, 1725-1752 (2020). https://doi.org/10.1007/s10653-019-00374-8

Adimalla, N., Venkatayogi, S. Geochemical characterization and evaluation of groundwater suitability for domestic and agricultural utility in semi-arid region of Basara, Telangana State, South India. Appl Water Sci 8, 44 (2018). https://doi.org/10.1007/s13201-018-0682-1

Agrawal, E., R., Garg, R.D. et al. Delineation of groundwater potential zone: An AHP/ANP approach. J Earth Syst Sci 122, 887-898 (2013). https://doi.org/10.1007/s12040-013-0309-8

Ali Haghizadeh, Davoud Davoudi Moghaddam and Hamid Reza Pourghasemi. GIS-based bivariate statistical techniques for groundwater potential analysis (an example of Iran), J. Earth Syst. Sci. (2017) 126:109, https://doi.org/10.1007/s12040-017-0888-x 
Arjun B. Doke, Rajendra B. Zolekar, Hemlata Patel, Sumit Das, Geospatial mapping of groundwater potential zones using multi-criteria decision-making AHP approach in a hardrock basaltic terrain in India, Ecological Indicators, Volume 127, 2021, 107685, ISSN 1470-160X, https://doi.org/10.1016/j.ecolind.2021.107685

Arjun Ram, S. K. Tiwari, H. K. Pandey, Abhishek Kumar Chaurasia, Supriya Singh, Y. V. Singh. Groundwater quality assessment using water quality index (WQI) under GIS framework., Applied Water Science (2021) 11:46 https://doi.org/10.1007/s13201-021-01376-7

Arulbalaji, P., Padmalal, D. \& Sreelash, K. GIS and AHP Techniques Based Delineation of Groundwater Potential Zones: a case study from Southern Western Ghats, India. Sci Rep 9, 2082 (2019). https://www.nature.com/articles/s41598-019-38567-x

C. Nair Nithya, Y. Srinivas, N.S. Magesh, S. Kaliraj, Assessment of groundwater potential zones in Chittar basin, Southern India using GIS based AHP technique, Remote Sensing Applications: Society and Environment, Volume 15, 2019, 100248, ISSN 2352-9385, https://doi.org/10.1016/j.rsase.2019.100248

Çelik, R. Evaluation of Groundwater Potential by GIS-Based Multicriteria Decision Making as a Spatial Prediction Tool: Case Study in the Tigris River Batman-Hasankeyf Sub-Basin, Turkey. Water 2019, 11, 2630. https://doi.org/10.3390/w11122630

Choudhury PR (1999) Integrated Remote Sensing and GIS Techniques for Groundwater Studies in Part of Betwa Basin Ph.D. Thesis (unpublished), Department of Earth Sciences, University of Roorkee, India.

Davoodi Moghaddam, D., Rezaei, M., Pourghasemi, H.R., Pourtaghie, Z.S., Pradhan, B., 2015. Groundwater spring potential mapping using bivariate statistical model and GIS in the taleghan watershed Iran. Arab. J. Geosci. 8 (2), 913-929

Debasis Ghosh, Mrinal Mandal, Monali Banerjee, Manas Karmakar, Impact of hydro-geological environment on availability of groundwater using analytical hierarchy process (AHP) and geospatial techniques: A study from the upper Kangsabati river basin, Groundwater for Sustainable Development, Volume 11, 2020, 100419, ISSN 2352-801X, https://doi.org/10.1016/j.gsd.2020.100419

Dempster A P 1967 Upper and lower probabilities induced by a multivalued mapping; Ann. Math. Stat. 38 325- 339.

Etishree, A., Rajat, A., Garg, R.D. and Garg, P.K, (2013). Delineation of groundwater potential zone: An AHP/ANP approach, Journal of Earth System Science. 122, 887-898.

Falah, F., Ghorbani Nejad, S., Rahmati, O., Daneshfar, M., Zeinivand, H., 2016. Applicability of generalized additive model in groundwater potential modelling and comparison its performance by bivariate statistical methods. Geocarto Int. https://doi.org/10.1080/10106049.2016.1188166.

Gangadharan R \& Nila Rekha P \& Vinoth S, Assessment of groundwater vulnerability mapping using AHP method in coastal watershed of shrimp farming area, Arab J Geosci (2016) 9:107 DOI 10.1007/s12517-015-2230-8

Gnanachandrasamy, G., Zhou, Y., Bagyaraj, M., Venkatramanan, S., Ramkumar, T., \& Wang, S. (2018). Remote sensing and GIS based groundwater potential zone mapping in Ariyalur District, Tamil Nadu. Journal of the Geological Society of India, 92(4), 484-490 https://link.springer.com/content/pdf/10.1007/s12594-0181046-z.pdf

H. K. Pandey, Report on District Ground Water Management Studies Mahoba District, U.P. CGWB-2002

India's Water Economy, Bracing for a Turbulent Future - 2006; Report No. 34750-IN, Agriculture and Rural Development Unit South Asia Region, Document of the World Bank

Islam, Z., Ranganathan, M., Bagyaraj, M., Singh, S. K., \& Gautam, S. K. (2021). Multi-decadal groundwater variability analysis using geostatistical method for groundwater sustainability. Environment, Development and Sustainability, 1-19.

Jac van der Gun, Chapter 24 - Groundwater resources sustainability, Editor(s): Abhijit Mukherjee, Bridget R. Scanlon, Alice Aureli, Simon Langan, Huaming Guo, Andrew A. McKenzie, Global Groundwater, Elsevier, 2021, Pages 331-345, ISBN 9780128181720, https://doi.org/10.1016/B978-0-12-818172-0.00024-4.

Koch M, Mather PM. 1997. Lineament mapping for groundwater resource assessment: a comparison of digital Synthetic Aperture Radar (SAR) imagery and stereoscopic Large Format Camera (LFC) photographs in the Red Sea Hills, Sudan. Int J Remote Sens. 18:1465-1482.10.1080/014311697218223 [Taylor \& Francis Online], [Google Scholar] 
Lamya Neissi, Mohammad Albaji, Saeed Boroomand Nasab, Combination of GIS and AHP for site selection of pressurized irrigation systems in the Izeh plain, Iran, Agricultural Water Management, Volume 231, 2020, 106004, ISSN 0378-3774, https://doi.org/10.1016/j.agwat.2020.106004

M. Cavur , H.S. Duzgun, S. Kemec , D. C. Demirkan., Land Use And Land Cover Classification Of Sentinel 2-a: St Petersburg Case Study, The International Archives of the Photogrammetry, Remote Sensing and Spatial Information Sciences, Volume XLII-1/W2, 2019

Mogaji, K.A., Lim, H.S., 2018. Application of Dempster-Shafer theory of evidence model to geoelectric and hydraulic parameters for groundwater potential zonation. NRIAG J. Astron. Geophys. https://doi.org/10.1016/j.nrjag.2017.12.008

Moore, I.D., Grayson, R.B., Ladson, A.R., 1991. Digital terrain modeling: a review of hydrological, geomorphological and biological applications. Hydrol. Process. 5, 3-30.

Murmu, P., Kumar, M., Lal, D., Sonker, I., Singh, S.K., 2019. In: Delineation of Groundwater Potential Zones Using Geospatial Techniques and Analytical Hierarchy Process in Dumka District, Jharkhand, vol. 9. Groundwater for Sustainable Development, India, p. 100239.

Nag S.K and Ghosh, P. (2012). Delineation of groundwater potential zone in Chhatna Block, Bankura District, West Bengal, India using remote sensing and GIS techniques. Environmental Earth Science. DOI 10.1007/s 12665012-1713-0.

Nithya, S.E., Jeeva, J., 2018. Groundwater potential mapping using Dempster - Shafer theory of Evidence for Tiruvannamalai district, India. Indian J. Ecol. 45 (3), 542-549.

Oh, H.J., Kim, Y.S., Choi, J.K., Park, E., Lee, S., 2011. GIS mapping of regional probabilistic groundwater potential in the area of Pohang City, Korea. J. Hydrol. 399, 158-172.

Ozdemir, A., 2011. GIS-based groundwater spring potential mapping in the Sultan Mountains (Konya, Turkey) using frequency ratio, weights of evidence and logistic regression methods and their comparison. J. Hydrol. 411 (3-4), 290-308.

Pande, C.B., Moharir, K.N., Singh, S.K., Varade, A.M., 2019. An Integrated Approach to Delineate the Groundwater Potential Zones in Devdari Watershed Area of Akola District, Maharashtra, Central India. Environment, Development and Sustainability, pp. 1-21.

Pourghasemi, H.R., Beheshtirad, M., 2014. Assessment of a data-driven evidential belief function model and GIS for groundwater potential mapping in the Koohrang Watershed. Geocarto Int. https://doi.org/10.1080/10106049.2014.966161.

Pourtaghi, Z.S., Pourghasemi, H.R., 2014. GIS-based groundwater spring potential assessment and mapping in the Birjand Township, southern Khorasan Province Iran. Hydrogeol. J. 22 (3), 643-662.

Rahmati, O., Nazari Samani, A., Mahdavi, M., Pourghasemi, H.R., Zeinivand, H., 2014. Groundwater potential mapping at Kurdistan region of Iran using analytic hierarchy process and GIS. Arab. J. Geosci. https://doi.org/10.1007/s12517-014-1668-4

Rodhe A., Seibert J., 1999. Wetland occurrence in relation to topography: a test of topographic indices as moisture indicators. Agric. For. Meteorol. 98-99, 325-340.

S Suganthi, L Elango and S K Subramanian, Groundwater potential zonation by Remote Sensing and GIS techniques and its relation to the Groundwater level in the Coastal part of the Arani and Koratalai River Basin, Southern India, Earth Sci. Res. SJ. Vol. 17, No. 2 (December, 2013): $87 \quad-\quad 95$ http://www.scielo.org.co/pdf/esrj/v17n2/v17n2a2.pdf

Sahereh Obeidavi, Mojtaba Gandomkar a , Gholamreza Akbarizadeh, Hossein Delfan. Evaluation of groundwater potential using Dempster-Shafer model and sensitivity analysis of effective factors: A case study of north Khuzestan province. Remote Sensing Applications Society and Environment. February 2021, DOI: 10.1016/j.rsase.2021.100475

Shafer, G.A., 1976. Mathematical Theory of Evidence. Princeton University Press, Princeton, pp. 1-24.

Shekhar, S., Pandey, A.C., 2014. Delineation of groundwater potential zone in hard rock terrain of India using remote sensing, geographical information system (GIS) and analytic hierarchy process (AHP) techniques. Geocarto Int. https://doi.org/10.1080/ 10106049.2014.894584. 
616

617

618

619

620

621

622

623

624

625

626

627

628

629

630

631

Singh, S., Singh, C., \& Mukherjee, S. (2010). Impact of land-use and land-cover change on groundwater quality in the Lower Shiwalik hills: a remote sensing and GIS based approach. Open geosciences, 2(2), 124-131.

Sreedevi PD, Srinivasulu S, Raju KK. 2001. Hydrogeomorphological and groundwater prospects of the Pageru river basin by using remote sensing data. Environ Geol. 40:1088-1094. [Crossref], [Google Scholar]

Suja Rose, R.S. and Krishnan, N. (2009). Spatial analysis of groundwater potential using remote sensing and GIS in the Kanyakumari and Nambiyar Basins, India, Journal of the Indian Society of Remote Sensing. 37, 681692.

Sumit Das, Comparison among influencing factor, frequency ratio, and analytical hierarchy process techniques for groundwater potential zonation in Vaitarna basin, Maharashtra, India, Groundwater for Sustainable Development, Volume 8, 2019, Pages 617-629, ISSN 2352-801X, https://doi.org/10.1016/j.gsd.2019.03.003

T.K. Pant, Assistant Hydrogeologist, CGWB, Ground Water Brochure Of Mahoba District, U.P. , http://cgwb.gov.in/District Profile/UP/Mahoba.pdf

Tehrany, M.S., Pradhan, B., Jebur, M.N., 2013. Spatial prediction of flood susceptible areas using rule based decision tree (DT) and a novel ensemble bivariate and multivariate statistical models in GIS. J. Hydrol. 504, 69-79.

V. Kannan, Benchmarking the service quality of ocean container carriers using AHP, Benchmark, 17(2010), pp. 637$656, \underline{10.1108 / 14635771011076416}$ 